\title{
Thermal mass and the effects on heating and cooling demands - an experimental study of an exposed concrete floor
}

\author{
Alessandro Nocente ${ }^{1, *}$, and Steinar Grynning ${ }^{1}$ \\ ${ }^{1}$ SINTEF Community, Trondheim, Norway
}

\begin{abstract}
The increase of thermal mass in buildings is discussed as a useful measure for reducing the energy demand for heating and cooling while contributing to improve the internal comfort. Several studies confirmed its positive effect, but few conducted a solid comparative measurement campaign and rarely in comparative conditions. The present work reports the results of an extensive comparative campaign in a test cell facility, where the internal conditions are measured in two identical rooms. One of the rooms was equipped with a large concrete mass while the other was constructed with a thin wooden floor. Measurements were conducted for circa a month, divided in four phases. The internal temperature of the two rooms was kept within typical boundaries of actual office rooms by a water-based cooling and heating systems. The energy demand of both heating and cooling was measured. Occupancy was simulated by a mannequin and by the lighting, both active only in office hours. The results demonstrated a positive impact of the thermal mass on the energy use. Since the test rooms are highly insulated, the energy use associated to cooling was dominant. During the experimental campaign, a reduction of up to $44 \%$ of the energy demand due to cooling was registered.
\end{abstract}

\section{Introduction}

Buildings of the future will be met by stricter demands for energy use. The increase in energy efficiency in buildings will be necessary to fulfil the goals fixed by Paris agreement. It is important, though, that this enhancement does not go to the detriment of the internal comfort. National and international regulations are the main driver for this improvement, as it happens in the Norwegian building regulation [1] where different measures are imposed to meet the energy requirements. One of the discussed measures is to increase the thermal mass of the building. A larger thermal mass is able to store energy in the form of heat, both as sensible and latent heat, and this can influence the internal comfort, the indoor temperature and the energy demand [2]. With a higher thermal inertia, it is possible to reduce the peak temperature during warm days thus reducing the cooling energy use, and to increase it at night thus reducing the demand of heating. If properly designed, the joint use of thermal masses and energy systems can allow for heat storage and release along a daily or longer cycle. As concluded by Høseggen [3], the main advantage of a high thermal mass is to decrease the temperature fluctuations during the day and to make the indoor climate more comfortable for the occupants.

One key factor is the thermal diffusivity of the material, i.e. the velocity at which the heat is absorbed. This depends on several characteristics such as the thermal conductivity of the exposed layer, the presence or absence of coating and the specific heat of the material [2]. Heavy materials have a high thermal capacity and are therefore able to store more heat [2], absorbed from the surrounding air or directly from the incident solar radiation. Concrete represents an obvious choice due to large availability and its normal presence in the construction industry.

The effect of thermal masses on the thermal behaviour of the building is a complex phenomenon. It depends on the properties of the material, the heat losses or heat gains in the room, the climatic conditions, the surface finishing and the exposition to solar radiations. Several studies analyse the Physics of this phenomenon with a theoretical perspective [4], but there are still few works reporting extensive comparative experimental campaigns [5]. According to Kalema et al. (2008) [6] there are at least two works in which this measurements are performed [7], [8]. Verbeke and Audenaert (2018) indicate the same studies. Another published work is by Givoni (1998) [9], where are presented measurements from three different test buildings without going through a comparative investigation. The peak temperature of a test building with heavy concrete external and partitioning walls was found to be more than $3^{\circ} \mathrm{C}$ lower than a lightweight construction given an outside temperature of $35^{\circ} \mathrm{C}$. None of the studies presents an investigation in which the heavy concrete mass is concentrated on the floor. Furthermore, all these studies were conducted on normal buildings, often poorly

* Corresponding author: alessandro.nocente@sintef.no 
insulated and in any case without performing an accurate comparative test.

This work, which builds up on previous studies by the authors presented in [10], presents the results of an extensive experimental campaign aimed to quantify the effect of a large thermal mass on the internal conditions of a single person office room.

\section{The ZEB Test Cell Laboratory}

The experimental campaign was conducted in the ZEB Test Cell Laboratory [11], at the Norwegian University of Science and Technology (NTNU). The facility is constituted by two identical rooms, the size of a typical one-person office room: (W x L x H) $2.4 \mathrm{~m} \times 4.2 \mathrm{~m} \times$ $3.3 \mathrm{~m}$. Each room is suspended in a dedicated guard space, the minimum clearance between the cell and the guard room is about $0.5 \mathrm{~m}$ (below the cell). The southern façade (Fig. 1) is exposed to outdoor weather and it is entirely replaceable. This allows to test different materials, solutions or building components. The façade used during this experiment includes a window with dimensions (W x H) $2.02 \mathrm{~m} \times 2.09 \mathrm{~m}$ [12]. The windows are equipped with an embedded solar shade that can be lowered by the central control computer. One of the glazing elements is mechanised and the system can be opened or closed on command or automatically as a response to measured parameters. The rest of the façade is a wood-frame construction with a $250 \mathrm{~mm}$ insulation thickness. The specifications of the southern façade are reported in Table 1.

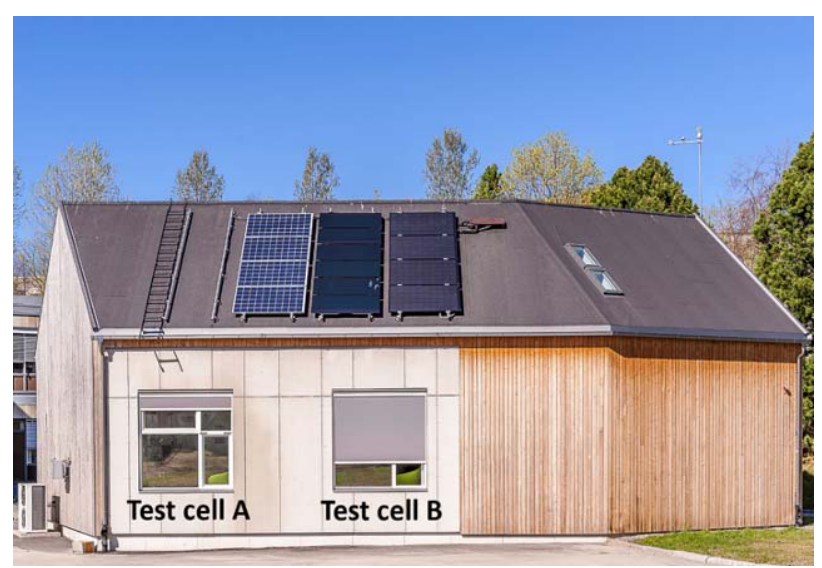

Fig. 1. The ZEB Test Cell Laboratory - view of the Southern façade

The internal walls of each room (i.e. the wall separating the test cell from the guard room) are made of prefabricated sandwich panels: stainless steel $(0.6 \mathrm{~mm})$ injected with polyurethane foam $(100 \mathrm{~mm})$. The U-value of the internal walls is $0.23 \mathrm{~W} / \mathrm{m}^{2} \mathrm{~K}$.

Each test room and each guard room are equipped with their independent HVAC system. The facility was designed to accommodate building envelope testing against outdoor weather, for both calorimetric and comparative tests.
Table 1. Test Cell facade characteristics

\begin{tabular}{|c|c|c|c|}
\hline $\begin{array}{c}\text { Façade } \\
\text { Component }\end{array}$ & $\begin{array}{c}\text { Area } \\
{\left[\mathbf{m}^{2}\right]}\end{array}$ & $\begin{array}{c}\mathbf{U} \text {-value } \\
{\left[\mathbf{W} / \mathbf{m}^{2} \mathbf{K}\right]}\end{array}$ & $\begin{array}{c}\text { G-value } \\
{[-]}\end{array}$ \\
\hline Window & 4.2 & 0.84 & - \\
\hline $\begin{array}{c}\text { Glazing Units } \\
\left(\mathrm{T}_{\text {vis }}=0.59\right)\end{array}$ & 3.1 & 0.62 & 0.38 \\
\hline $\begin{array}{c}\text { Opaque façade } \\
\text { area }\end{array}$ & 3.7 & 0.20 & - \\
\hline
\end{tabular}

However, the large number of sensors and systems together with the high flexibility of the control software, makes the Test Cell an ideal test arena for any experiment that requires a large controlled environment.

\section{Experimental Setup}

For the experiment object of this work one of the cells (Cell B) was equipped with a large thermal mass (Fig. 2), constituted by $70 \mathrm{~mm}$ thick concrete floor tiles, each of dimensions (W x L) $700 \mathrm{~mm} \times 800 \mathrm{~mm}$. The total mass added to the cell is circa $2000 \mathrm{~kg}$. The second cell (Cell A) was instead constructed with a $18 \mathrm{~mm}$ thick wooden floor. Both cells were equipped with 15 type-T thermocouples (average uncertainty $\pm 0.5^{\circ} \mathrm{C}$ ) to measure the surface temperature, distributed on the internal surfaces. The surface temperature of the southern façade was measured by 4 thermocouples on the glazing units.
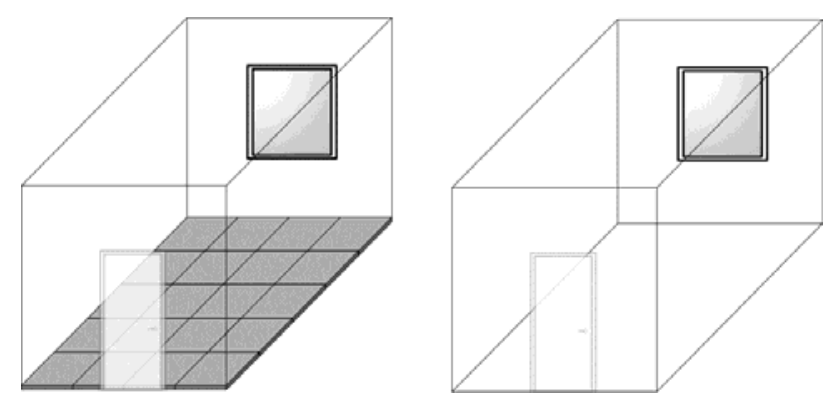

Fig. 2. Thermal mass in the test rooms: Cell B (left) and Cell A (right)

Air temperature was measured by 5 Pt- 100 thermometers $\left( \pm 0.1^{\circ} \mathrm{C}\right.$ typical uncertainty) mounted on two masts, one in the centre of the room and one in the corner close to the access door. The sensors were placed on the central mast at 100,600 and $1100 \mathrm{~mm}$ from the floor, while the Pt-100 on the corner mast were placed at 600 and $1100 \mathrm{~mm}$ from the floor. A black globe thermometer was suspended in the geometrical centre of the room at a height of $1500 \mathrm{~mm}$. The superficial temperature of the thermal mass was recorded by T-Type thermocouple 
above and below the concrete on two tiles (Fig. 3). The instrumented tiles were placed on the midfloor line at $1400 \mathrm{~mm}$ and $2800 \mathrm{~mm}$ from the window.

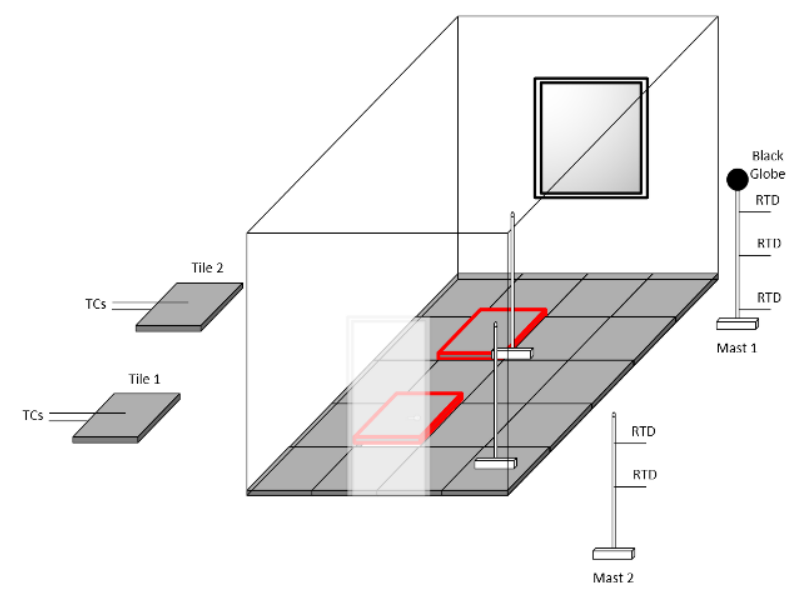

Fig. 3. Measurement points of air, radiant and thermal mass surface temperature

The internal space was heated and cooled when needed by a radiator and a fan coil, which made use of the hot/chilled water circuit of the facility. The inlet water temperatures were kept constant in both cases by PID controllers acting on a three-way valve for each circuit, placed immediately out of the internal wall at the connection with the room internal piping. Downstream of the three-valve the thermal energy carried by each circuit was measured using a Kamstrup Multical 602 energy meter. Outdoor temperature, humidity and solar radiation on vertical and horizontal planes were acquired by the weather station mounted on the roof of the laboratory.

During the measurement campaign, both cells were subject to an internal gain of $180 \mathrm{~W}$ due to the neon tube illumination. In addition, $100 \mathrm{~W}$ internal gain was provided by a mannequin. Both the mannequin and the lights were temporised and active only on weekdays in office hours, from 8:00 am to 4:00 pm. The internal gain due to the sensors and a part of the acquisition system present in the cell was continuously acquired, and never exceeded $11 \mathrm{~W}$.

\section{Experimental Procedure}

For the whole duration of the experiment the ventilation system of the cells was sealed. The internal temperature was kept within a constant interval.

The Test Cell control and acquisition system measured the averaged air temperature and activated the radiator between $21^{\circ} \mathrm{C}$ and $23^{\circ} \mathrm{C}$, and the fan coil between $24^{\circ} \mathrm{C}$ and $26^{\circ} \mathrm{C}$ to simulate the temperature boundaries of actual offices. Data logging interval was set to $60 \mathrm{~s}$. Data acquisition was carried out in 4 phases for a minimum duration of 9 days each.

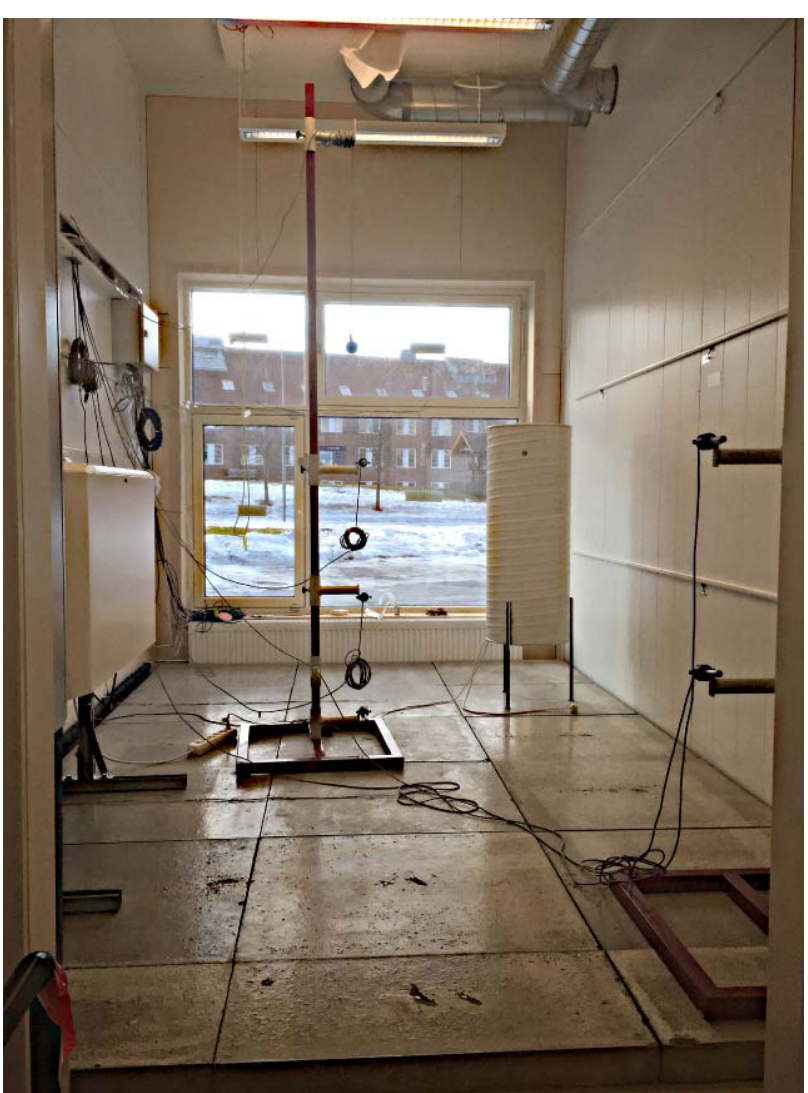

Fig. 4. Internal view of cell B (with concrete floor)

Table 2. Dates and characteristics of the 4 phases of measurement acquisition

\begin{tabular}{|c|c|c|c|c|}
\hline $\begin{array}{c}\text { Experiment } \\
\text { Phase }\end{array}$ & $\begin{array}{c}\text { Solar } \\
\text { Shade }\end{array}$ & $\begin{array}{c}\text { Natural } \\
\text { Ventilation }\end{array}$ & Dates & Days \\
\hline A & & & $19 / 03-27 / 03$ & 9 \\
\hline B & & X & $29 / 03-07 / 04$ & 10 \\
\hline C & $\mathbf{X}$ & & $09 / 04-22 / 04$ & 13 \\
\hline D & $\mathbf{X}$ & $\mathbf{X}$ & $23 / 04-04 / 05$ & 12 \\
\hline
\end{tabular}

Table 2 reports the four investigation phases, indicated with letters from $\mathrm{A}$ to $\mathrm{D}$, the presence or absence of solar shading and natural ventilation and the time of measurement. In phase A the cells were kept without solar shading and natural ventilation. Phase $\mathrm{B}$ and $\mathrm{C}$ were conducted with the solar shading down. In phase B and $\mathrm{D}$, the system provided the opening of the mechanised section of the windows whenever the temperature of the room exceeded $26^{\circ} \mathrm{C}$. In this case the small opening of the tilted window and absence of internal mechanical ventilation resulted in a limited amount of air entering the test cell and substantial negligible effect on the internal temperature. 


\section{Results}

Figure 5 presents the black globe temperature in the two cells registered during each phase of the experiment. The blue line represents the outdoor temperature acquired by the weather station of the facility. Figure 6 reports the temperatures registered above and below the thermal mass (Tile 2, cfr. Fig. 3) together with the outdoor temperature (blue line) and the solar radiation (red). As reported earlier, both the cooling and the heating systems are water based. The energy demand of the heating and cooling systems was therefore calculated by the energy meter based on the measured flow rate and the temperature of the water flow entering and leaving the cell. The data on energy demand obtained from the energy meter are, due to the sensor characteristics, rounded to the nearest $10 \mathrm{Wh}$. The uncertainty of the whole measurement chain is expected to be fully within $\pm 10 \mathrm{Wh}$. The energy use is reported for both heating (Tab. 3) and cooling (Tab. 4) for each investigation phase.

Table 3. Heating demand during each experiment phase for Cell A and Cell B (cell with thermal mass)

\begin{tabular}{|l|l|l|}
\hline Phase & Cell A [Wh] & Cell B [Wh] \\
\hline A & 0 & 0 \\
\hline B & 0 & 0 \\
\hline C & 80 & 80 \\
\hline D & 40 & 50 \\
\hline
\end{tabular}

Table 4. Cooling demand during each experiment phase for Cell A and Cell B (cell with thermal mass)

\begin{tabular}{|l|l|l|}
\hline Phase & Cell A [Wh] & Cell B [Wh] \\
\hline A & 20 & 14 \\
\hline B & 25 & 15 \\
\hline C & 110 & 60 \\
\hline D & 140 & 80 \\
\hline
\end{tabular}

\section{Discussion}

From Figure 5, it is possible to notice a general trend where the black globe temperature in cell B (green line) decreases more slowly than in cell A during night-time. This result was expected. During the day the internal temperature presents ripples corresponding to the activation and deactivation of the cooling system. Is possible to notice that the frequency of the ripples in cell $\mathrm{B}$ tends to be smaller, and especially the increase of temperature tends to be slower. During the weekends the automated cooling/heating system was still on, but the internal gain was excluded. This translates in the absence of ripples during those days.

The good insulation of the cells and the absence of ventilation makes the internal gain of circa $280 \mathrm{~W}$ enough to warm up the cells for most of the test period. The data in Table 3 show no substantial difference between the heating energy demand in the two cells. For phases $\mathrm{A}$ and $\mathrm{B}$, when there is no solar screen applied to the windows, the energy use is negligible. In phases $\mathrm{C}$ and $\mathrm{D}$ there is a certain amount of power used to heat the cells, and in this case the amount is circa the same for both cells. Although the main difference between phases $\mathrm{A}$ and $\mathrm{B}$ and phases $\mathrm{C}$ and $\mathrm{D}$ is the presence of solar screen, a deeper analysis of the data seems to suggest that the difference is caused by the lower outdoor temperature. In fact, the heating system is mainly active at night for the reasons explained so far. Furthermore, outdoor temperature between the first two phases and the second two present a different trend, with higher variation between day and night, and this is typical for that period and in case of clear sky.
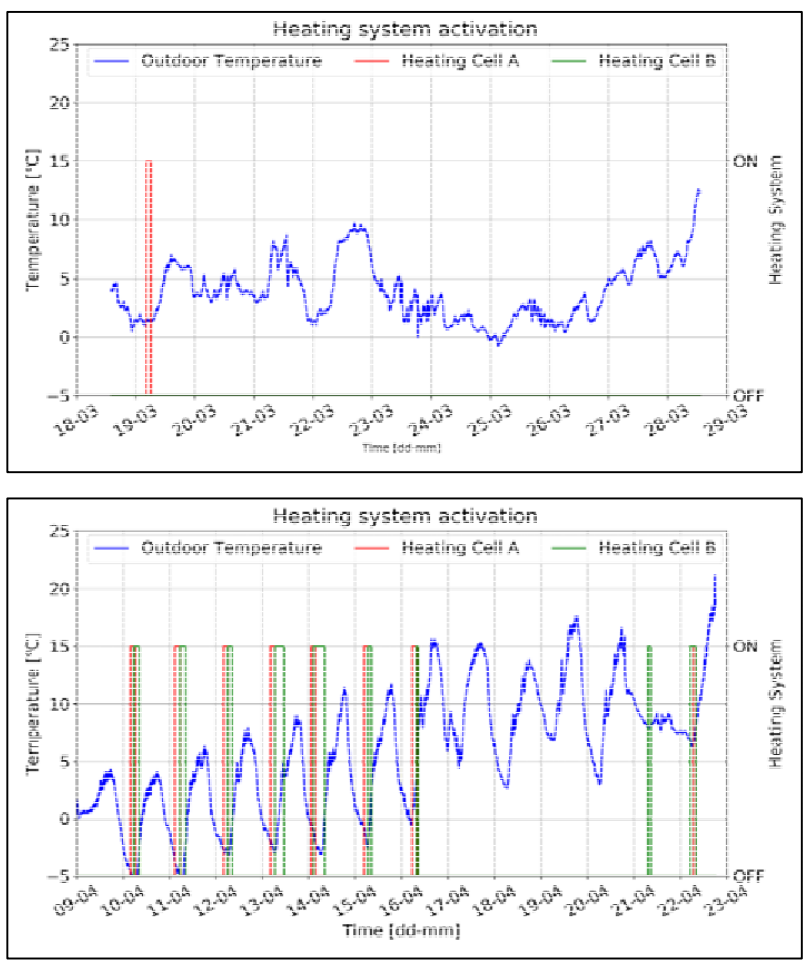

Fig. 7. Automatic activation of the heating system in the two cells for phase A (upper) and C (lower)

Figure 7 compares the outdoor temperature in phases A and $\mathrm{C}$, as example of two phases with different outdoor conditions. As shown, the heating system was not necessary in phase A except for a small amount of time in cell A (red line in Fig. 7). The energy use associated to that was anyway negligible, i.e. negligible temperature 

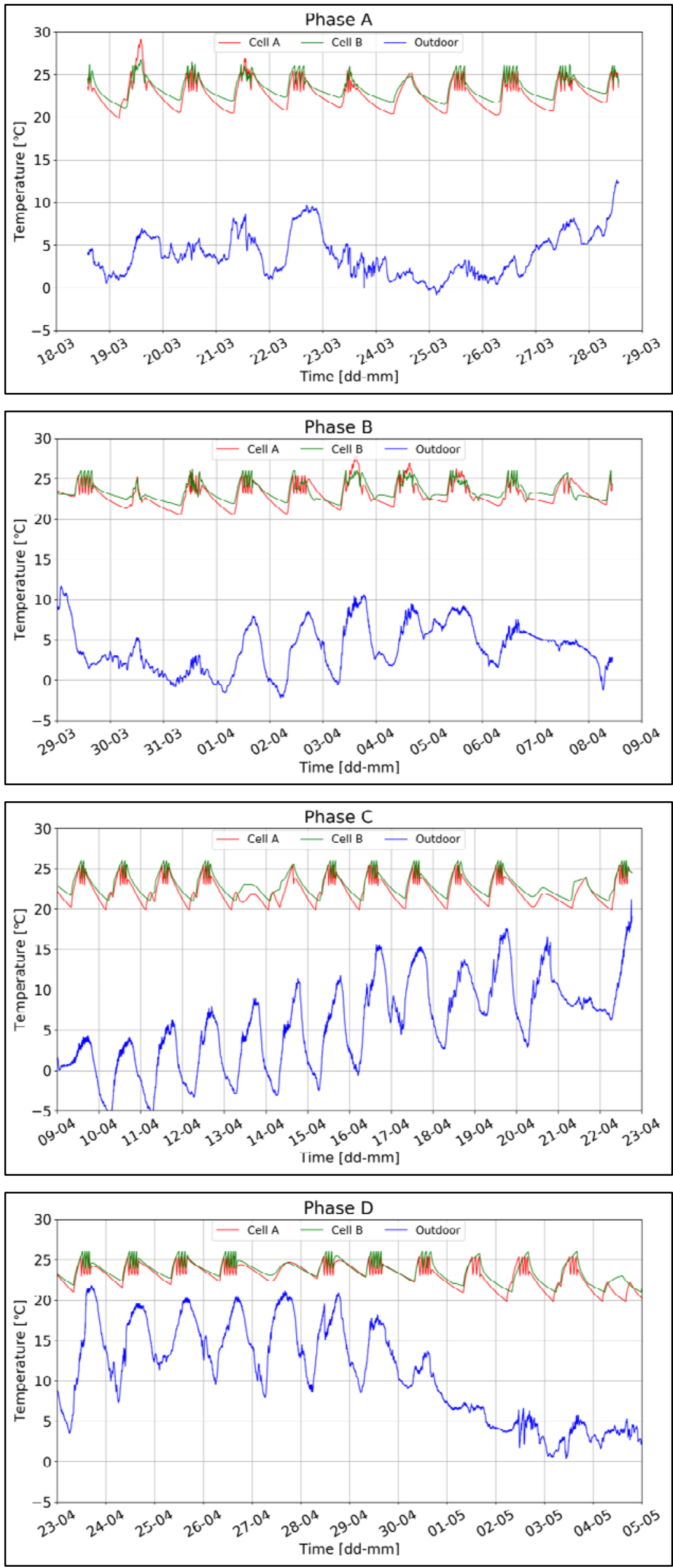

Fig. 5. Cell temperatures recorded during the experiment 

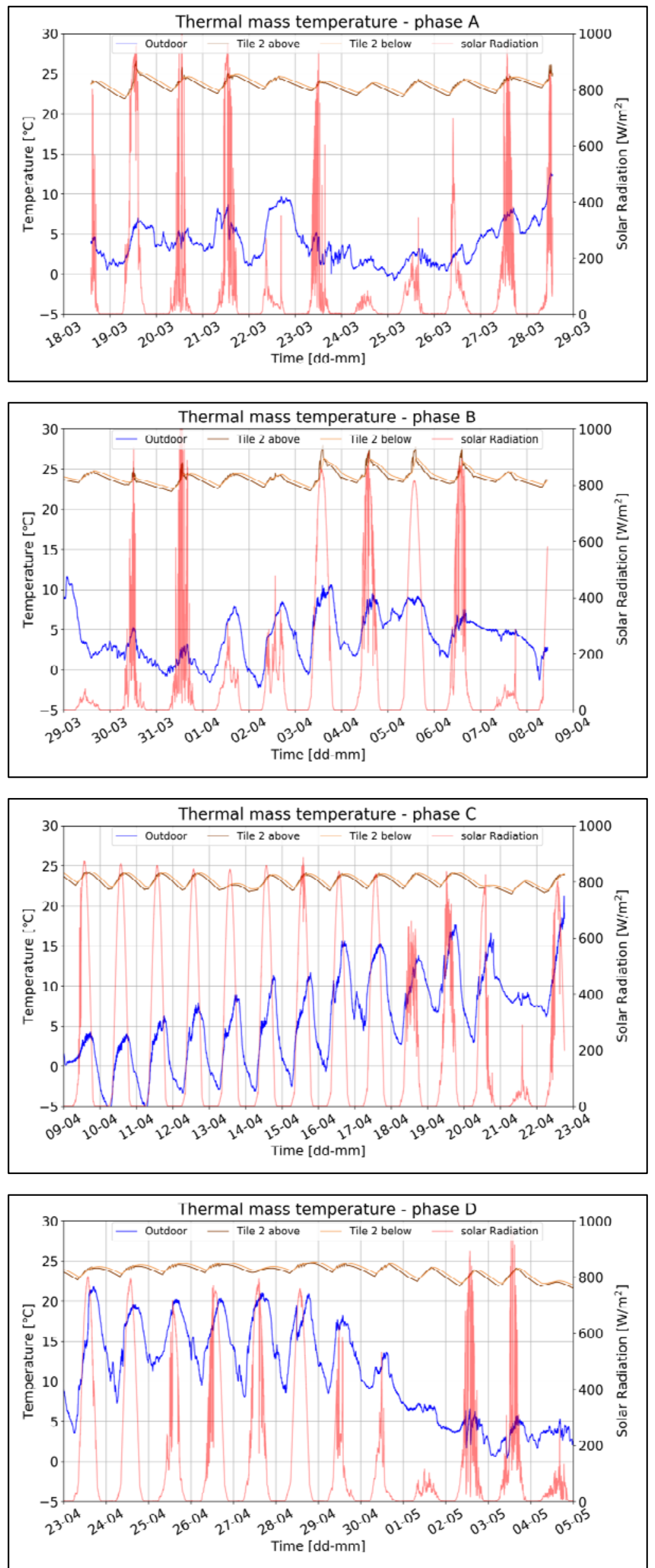

Fig. 6. Temperature above and below Tile 2 for the 4 experimental phases 
difference between inlet and outlet water. In phase $\mathrm{C}$ the heating system is active at night when lower outdoor temperatures are registered, without appreciable difference between the cells except a general time delay in cell $\mathrm{B}$ due to the higher thermal inertia of the concrete mass.

A clearly different situation is evident for what concerns the energy use related to cooling (Tab. 4). The activation of the cooling system is always needed in weekdays to balance the increase in temperature due to the internal gain. In this case the energy savings is on average 35\% in the cell with thermal mass with respect to the other cell for phases A and B. For phases $\mathrm{C}$ and $\mathrm{D}$, the average energy saving reaches $44 \%$. The difference in the experimental setup only consists in the use of the solar shading, therefore this should be ascribed to the reduction of heat losses due to the shading device. The energy saving is evaluated within the temperature limits indicated in the previous sections. Its value is strictly dependent on the choice of temperature boundaries. If a different indoor temperature is considered acceptable for users' comfort, different results are expected.

\section{Conclusions}

An extensive experimental campaign in a large-scale laboratory facility was carried out to investigate how the presence of a large thermal mass, represented by an exposed concrete floor, influence the energy demand for heating and cooling in a single person office room. The measurements were compared to those acquired in an identical room only equipped with a thin wooden floor. A water-based heating and cooling system was used to keep the internal temperature within a range considered typical for offices. Based on the water entering and leaving the heating and cooling systems, it was calculated the energy use to evaluate the influence of the thermal mass.

The obtained data demonstrated the positive influence of the thermal mass on the energy demand. The rooms are part of a highly insulated facility, designed to test heat losses only through the façade, exposed to outside weather. Despite the rather low outdoor temperatures registered during the measurement campaign, the energy use related to the heating of the internal environment results low. This happens mainly at night, and the difference in magnitude does not present significant difference between the two rooms. Nevertheless, the activation of the heating system results delayed in the room equipped with a concrete floor, as expected, due to the higher thermal inertia.

A different situation was observed with regard to the cooling system. The cooling system is activated during office hours, to counteract the internal gain represented by the lighting system and the mannequin used to simulate an occupant and a low power consumption office equipment (i.e. laptop). One first evidence given by the results underlines the fact that energy demand in heavily insulated office building is cooling dominated even in cold climates.
The presence of a large thermal mass contributes evidently to the reduction of the required energy for cooling. As it was observed, an average reduction by $35 \%$ of the energy use is measured when the solar shading system is not used. When the solar shading was kept down for the whole duration of the last two phases of the experiments, the saving in cooling energy reached an average of $44 \%$.

The measurements also represent a valid dataset for the validation and the calibration of simulations models which are being developed to evaluate the reduction in energy demand for full scale office buildings.

This work is supported by the Research Council of Norway and several partners through the Research Centre on Zero Emission Neighbourhoods in Smart Cities (FME ZEN) under grant No. 257660.

This paper is also supported by the SkinTech project funded by the Research Council of Norway under grant No. 255252 and the industrial partners in the project.

The authors wish to thank the industrial partner Norcem AS - Heidelberg Cement Group for their support in this research.

\section{References}

1. K. Regionaldepartementet, "Byggteknisk Forskrift (TEK17)," Lovdata, JUN, 2017.

2. M. J. Alonso and H. M. Mathisen, "Analysis of reduction of energy demands for Zero Emission Renovated Office Building by using thermal mass and ventilative cooling," Energy Procedia, 132, pp. 592-597, 2017.

3. R. Z. Høseggen, "Dynamic use of the building structure-energy performance and thermal environment," 2008.

4. S. Ø. Jensen et al., "IEA EBC Annex 67 Energy Flexible Buildings," Energy Build., 155, 2017, pp. 25-34, 2017.

5. S. Verbeke and A. Audenaert, "Thermal inertia in buildings: A review of impacts across climate and building use," Renew. Sustain. Energy Rev., 82, pp. 2300-2318, 2018.

6. T. Kalema, G. Jóhannesson, P. Pylsy, and P. Hagengran, "Accuracy of energy analysis of buildings: a comparison of a monthly energy balance method and simulation methods in calculating the energy consumption and the effect of thermal mass," J. Build. Phys., 32, 2, pp. 101-130, 2008.

7. T. Kalema and H. Martikainen, "The effect of buildings' structures and the heat distribution system on the heating energy of a single-family house (in Finnish)," 1987.

8. R. Lindberg, A. Binamu, and M. Teikari, "Fiveyear data of measured weather, energy consumption, and time-dependent temperature variations within different exterior wall 
structures," Energy Build., 36, 6, pp. 495501, 2004.

9. B. Givoni, "Effectiveness of mass and night ventilation in lowering the indoor daytime temperatures. Part I: 1993 experimental periods," Energy Build, 28, 1, pp. 25-32, 1998.

10. S. Grynning, A. Nocente, L. Gullbrekken, and K. Skjeggerud, "Thermal mass and thermal comfort in offices - experimental studies of a concrete floor," MATEC Web Conf., 2019.
11. F. Goia, C. Schlemminger, and A. Gustavsen, "The ZEB Test Cell Laboratory. A facility for characterization of building envelope systems under real outdoor conditions," Energy Procedia, 132, pp. 531-536, Oct. 2017.

12. J. Brozovsky, M. Haase, A. Nocente, and N. Lolli, "Towards validation of a numerical model of a test cell laboratory," in 7th International Building Physics Conference, IBPC2018, 2018, pp. 67-72. 